\title{
Histopathology, ultrastructure and immunohistochemistry of Coregonus lavaretus hearts naturally infected with Ichthyocotylurus erraticus (Trematoda)
}

\author{
Bahram Sayyaf Dezfuli ${ }^{1, *}$, Luisa Giari ${ }^{1}$, Edi Simoni $^{1}$, Andrew Paul Shinn ${ }^{2}$, \\ Maurizio Manera ${ }^{3}$, Giampaolo Bosi ${ }^{4}$ \\ ${ }^{1}$ Department of Biology, University of Ferrara, Via Borsari, 46, 44100 Ferrara, Italy \\ ${ }^{2}$ Institute of Aquaculture, University of Stirling, Stirling FK9 4LA, UK \\ ${ }^{3}$ Department of Alimentary Sciences, University of Teramo, Piazza Aldo Moro 45, 64100 Teramo, Italy \\ ${ }^{4}$ Department of Veterinary Sciences and Technologies for Food Safety, University of Milan, Via Trentacoste 2, \\ 20134 Milan, Italy
}

\begin{abstract}
Histopathological, ultrastructural and immunohistochemical investigations were conducted on 26 specimens of powan Coregonus lavaretus (L.) from Loch Lomond (Scotland). The hearts of all 26 powan (15 females and 11 males) investigated harboured metacercariae of the digenean trematode Ichthyocotylurus erraticus (Rudolphi, 1809). The vast majority of metacercariae were located either singly or as an aggregation of white cysts on the surface of the bulbus arteriosus. The intensity of infection ranged from 2 to 200 larvae heart $^{-1}$, although the number of metacercariae found on male powan did not exceed 13. Histochemically, the parasite cyst wall gave a strong positive reaction with periodic acid schiff (PAS) and a faint positive signal with Azan-Mallory stain. All the metacercariae cysts were embedded in a granulomatous proliferation of heart epicardium tissue, forming a reactive fibroconnective capsule around the parasite. The capsule enclosing the parasite (produced by the host's reaction to the parasite) measured 13.57 to $90.20 \mu \mathrm{m}(37.43 \pm 3.56)$ in thickness. Within the capsule wall, eosinophilic granular cells (EGCs), granulocytes, melanocytes and, in some instances, partially degenerated or vacuolated epithelioid cells were observed in close proximity to the cyst wall. Pigment-bearing macrophages were scattered throughout the granulomatous host-tissue reaction and as macrophage aggregates (MAs) within the capsules surrounding parasites. Immunohistochemical tests were applied to infected heart sections using 12 different antisera. Nerve fibres immunoreactive to bombesin, substance P (SP), and atrial natriuretic peptide (ANP) antisera were observed in close proximity to the parasite larvae. The presence of a serotonin-like substance was also observed within host immune-cells surrounding trematode cysts. Large cells of the epicardium were found to be immunoreactive to met-enkephalin and vasoactive intestinal peptide (VIP) antisera but not immunoreactive to anti-protein gene-product 9.5 (PGP9.5) sera.
\end{abstract}

KEY WORDS: Trematode infection · Immunohistochemistry $\cdot$ Neuromodulators $\cdot$ Heart $\cdot$ Coregonus lavaretus Resale or republication not permitted without written consent of the publisher

\section{INTRODUCTION}

The Scottish powan Coregonus lavaretus (L.) (Coregonidae) is endemic to Loch Lomond and Loch Eck (Pomeroy 1991) and its life history and its plathyhelminth infections have been detailed by Brown \&
Scott (1994) and Dolezel \& Crompton (2000) respectively. Of the metazoan parasites recorded from Coregonus, it has been suggested that high burdens of Ichthyocotylurus erraticus (Rudolphi, 1809) (Trematoda: Strigeidae) metacercariae can induce host mortality (Orecka-Grabda 1991, D. Griffiths pers. comm.). 
While this may or may not be the case, Blair (1976, 1977) suggested that the cercariae of British strigeoids were not the direct cause of fish mortalities. Tort et al. (1987), however, noted changes in the in vitro performance of rainbow trout, Oncorhynchus mykiss (Walbaum), hearts infected with Apatemon gracilis (Rudolphi, 1819), whereby the cardiac output of infected hearts was 20 to $40 \%$ lower than that of healthy hearts. Of the records focusing specifically on $I$. erraticus infections, there are only 2 records which deal with the host's tissue reaction (Orecka-Grabda 1991, Dolezel \& Crompton 2000) but neither provides an adequate description that is supported by light or electron microscopical examination of infected tissue. During the present study, aggregates of macrophages (MAs) were noted within the fibroconnective capsule surrounding the metacercariae of I. erraticus. Although there is no accepted view regarding the role of MAs in fishes, their proliferation is frequently associated with a variety of pathological and physiological factors (Vogelbein et al. 1987, Wolke 1992, Couillard et al. 1999). This paper therefore attempts to establish a relationship between the MAs and the digenean larvae on heart tissue, and comments on the histopathology and ultrastructure of the tissue at the site of the host-parasite interface.

In vertebrates, endoparasitic helminths can cause structural modification to the host tissue and induce alterations to the normal physiology of the host (Castro 1992, Fairweather 1997). It is well known that the diffuse endocrine, nervous and immune systems cooperate to elicit host responses to these helminths (Fairweather 1997) and to achieve this signal molecules (herein neuromodulators) are involved in communicating between the cells of the 3 systems (O'Dorisio \& Panerai 1990). The presence of neuromodulators in other host-parasite systems have been studied, including the effect of Pomphorhynchus laevis (Müller, 1776) and $C y$ athocephalus truncatus (Pallas, 1781) on the gut neuroendocrine system of Salmo trutta L. (see Dezfuli et al. 2000, 2002b, 2003a) and that of the protozoan Glugea anomala (Moniez, 1887) on the peripheral nervous system of Gasterosteus aculeatus L. (Dezfuli et al. 2004). These studies suggested that the presence of a parasite within a host induces the formation of a new network of nervous fibres at the inflammatory site, as demonstrated by the presence of a number of neurotransmitters (e.g. bombesin, galanin and substance P) at the site of infection (Dezfuli et al. 2002b, 2004). While a similar response may be expected by the powan-digenean system, given the lack of information on the nervous system of parasitised and uninfected heart tissue, our study assesses the occurrence of a range of neuropeptides in the hearts of Coregonus lavaretus parasitised with the metacercariae of Ichthyocotylurus erraticus.

\section{MATERIALS AND METHODS}

The hearts of 26 powan measuring 28 to $37 \mathrm{~cm}$ in fork length (mean $\pm \mathrm{SE}=32.03 \pm 0.63 \mathrm{~cm}$ ) were analysed following their collection in 2 gill net samples (July 2003, August 2004) taken in Loch Lomond in close proximity to the Glasgow University Field Station at Rowardennan (approximately $25 \mathrm{~km} \mathrm{NW}$ of Glasgow, UK, $53^{\circ} 10.0^{\prime} \mathrm{N}, 4^{\circ} 39.1^{\prime} \mathrm{W}$ ). The fish were given a lethal dose of the anaesthetic MS222 (Sandoz), then weighed and measured before severing the spinal cord. The fish were then dissected ventrally, sexed and the hearts observed in situ. The position of metacercarial cysts on the heart and/or the surrounding pericardial tissue were noted for each fish before carefully removing the heart and fixing it in chilled $\left(4^{\circ} \mathrm{C}\right)$ Bouin's fluid for $7 \mathrm{~h}$. The samples were then transferred to $70 \%$ alcohol and dehydrated through a graded alcohol series and prepared for paraffin embedding. Cut sections ( $7 \mu \mathrm{m}$ thick) were stained with either haematoxylin-eosin, Azan-Mallory, periodic acid Schiff (PAS) and alcian blue/PAS stains or used for immunohistochemical analysis. Heart sections were processed using the indirect immunohistochemical method (peroxidase-anti-peroxidase immunocomplex) as outlined in Dezfuli et al. (2002a, 2003b). The antisera, the working dilution and the incubation time used for each of the neuromodulators are detailed in Table 1. Controls for the specificity of the immunohistochemical reactions were obtained by pre-absorption of each antiserum with the corresponding antigen (Table 2). The control for the anti-protein gene-product 9.5 (PGP9.5) serum was obtained by incubating the sections with rabbit normal serum using the same conditions considered for the primary antiserum. Mammalian (pig, rat) tissue sections were used as positive controls.

For the light and electron microscopy study, heart tissues measuring up to $7 \times 7 \mathrm{~mm}$ in diameter were fixed for $2 \mathrm{~h}$ in chilled $\left(4^{\circ} \mathrm{C}\right) 2 \%$ glutaraldehyde solution buffered at $\mathrm{pH} 7.2$ with $0.1 \mathrm{M}$ sodium cacodylate. Thereafter, the pieces were rinsed for $12 \mathrm{~h}$ with $0.1 \mathrm{M}$ sodium cacodylate buffer containing $6 \%$ sucrose. The tissues were then post-fixed in $1 \%$ osmium tetroxide in the same buffer for $2 \mathrm{~h}$, dehydrated through a graded ethanol series, transferred to propylene oxide and then embedded in an Epoxy-Araldite ${ }^{\circledR}$ mixture. Semi-thin sections $(5 \mu \mathrm{m})$ were cut on a Reichert Om U2 ultramicrotome and stained with azure-A-methylene blue. Ultra-thin sections $(90 \mathrm{~nm})$ were stained with a solution of $4 \%$ uranyl acetate in $50 \%$ alcohol and Reynold's lead citrate and examined using a Zeiss EM9 transmission microscope. A Student's $t$-test (signifance level $\mathrm{p}=$ 0.05 ) was used to calculate the probability value for the total length, the weight and the number of metacercariae found in the 2 sexes of the host. 
Table 1. Primary antisera used in present study. ANP: atrial natriuretic peptide; CGRP: calcitonin gene-related peptide; NOS: nitric oxide synthase; NPY: neuropeptide tyrosine; PGP9.5: protein gene product 9.5; SP: substance P; VIP: vasoactive intestinal peptide; RT: room temperature

\begin{tabular}{|c|c|c|c|c|}
\hline $\begin{array}{l}\text { Antisera raised } \\
\text { in rabbit }\end{array}$ & Code & Source & Dilution & Incubation \\
\hline ANP & IHC 8798 & Peninsula Laboratory (Belmont, CA, USA) & $1: 200$ & $24 \mathrm{~h}$ at RT \\
\hline Bombesin & $1400-0004$ & Biogenesis (Poole, UK) & $1: 200$ & Overnight at $4^{\circ} \mathrm{C}$ \\
\hline CGRP & IHC 7181 & Peninsula Laboratory (Belmont, CA, USA) & $1: 400$ & $24 \mathrm{~h}$ at $4^{\circ} \mathrm{C}$ \\
\hline Galanin & T-4330 (IHC 7153) & Peninsula Laboratory (Belmont, CA, USA) & $1: 500$ & Overnight at $4^{\circ} \mathrm{C}$ \\
\hline Met-enkephalin & IHC 8602 & Peninsula Laboratory (Belmont, CA, USA) & $1: 500$ & Overnight at $4^{\circ} \mathrm{C}$ \\
\hline Met-enkephalin & AB 1975 & Chemicon (Temecula, CA, USA) & $1: 500$ & Overnight at $4^{\circ} \mathrm{C}$ \\
\hline NOS & sc-648 & Santa Cruz Biotechnologies (Santa Cruz, CA, USA) & $1: 200$ & Overnight at $4^{\circ} \mathrm{C}$ \\
\hline NPY & $6730-0004$ & Biogenesis (Poole, UK) & $1: 50$ & $24 \mathrm{~h}$ at $4^{\circ} \mathrm{C}$ \\
\hline PGP9.5 & AB 1761 & Chemicon (Temecula, CA, USA) & 1:1000 & Overnight at $4^{\circ} \mathrm{C}$ \\
\hline Serotonin & AB 938 & Chemicon (Temecula, CA, USA) & 1:1000 & Overnight at $4^{\circ} \mathrm{C}$ \\
\hline SP & T-4107 (IHC 7451) & Peninsula Laboratory (Belmont, CA, USA) & $1: 500$ & Overnight at $4^{\circ} \mathrm{C}$ \\
\hline VIP & $9535-0204$ & Biogenesis (Poole, UK) & $1: 50$ & $4 \mathrm{~h}$ at $\mathrm{RT}$ \\
\hline
\end{tabular}

Table 2. Peptides used for absorption controls. Abbreviations as in Table 1

\begin{tabular}{|lll|}
\hline Peptide & Code & \multicolumn{1}{c|}{ Source } \\
\hline ANP & A 1663 & Sigma Chemicals (St. Louis, MO, USA) \\
Bombesin & B 4272 & Sigma Chemicals (St. Louis, MO, USA) \\
CGRP & H 4924 & Bachem AG (Bubendorf, Switzerland) \\
Galanin & H 1365 & Bachem AG (Bubendorf, Switzerland) \\
Met-enkephalin & H 2785 & Bachem AG (Bubendorf, Switzerland) \\
NOS & Sc-648 P & Santa Cruz Biotechnologies (Santa Cruz, CA, USA) \\
NPY & H 6375 & Bachem AG (Bubendorf, Switzerland) \\
Serotonin & H 9523 & Sigma Chemicals (St. Louis, MO, USA) \\
SP & H 1890 & Bachem AG (Bubendorf, Switzerland) \\
VIP & V 3628 & Sigma Chemicals (St. Louis, MO, USA) \\
\hline
\end{tabular}

Stained sections were examined using a standard Olympus BX51 light microscope and digital images were obtained using the program DP-Soft (Olympus).

\section{RESULTS AND DISCUSSION}

The hearts of all 26 powan were infected with the metacercarial cysts of Ichthyocotylurus erraticus. The vast majority of parasite cysts were observed either singly or as an aggregation of white cysts (Fig. 1) on the surface of the bulbus arteriosus, while others were found either on the pericardium surrounding the ventricle, on the ventricle, or in the region between the ventricle and the bulbus arteriosus. Where metacercarial cysts were present in large numbers, it was observed that occasionally the mass of cysts caused adhesion between the parietal and visceral pericardial serosa. For the hearts of the 11 male powan, a total of 38 metacercariae were encountered with an intensity of 2 to 13 parasites ind. ${ }^{-1}$. For the hearts of 15 female powan, however, a total of 591 metacercariae were recorded at intensities ranging from 4 to 200 metacercariae heart ${ }^{-1}$. Among the entire sample of powan, the 2 largest females, with fork lengths of 36 and $37 \mathrm{~cm}$, had the highest intensities of infection (170 and 200 metacercariae respectively). Female powan therefore had a significantly higher number of metacercariae than male powan $(t=2.23, \mathrm{p}<0.05)$. The female powan (mean fork length $33.47 \pm$ $0.81 \mathrm{SE} \mathrm{cm}$, mean weight $392.53 \pm$ 19.20 SE g) were longer $(t=3.22, \mathrm{p}<$ $0.01)$ and heavier $(t=2.66, \mathrm{p}<0.02)$ than males (mean fork length $30.09 \pm 0.67 \mathrm{SE} \mathrm{cm}$, mean weight $306.09 \pm 25.55 \mathrm{SE} \mathrm{g}$ )

The majority of metacercarial cysts found were embedded in a granulomatous proliferation of heart epicardial tissue (Fig. 1), but in a few instances cysts were present within the heart myocardium (Fig. 2). The manner of attachment of the Ichthyocotylurus erraticus cysts to the heart muscle also varied greatly, most metacercariae being embedded in the connective tissue with a loose connection to the epicardium (Fig. 1). In other cases, in which the cyst was firmly attached to the heart and depressed the muscle layers beneath it, the epicardium enclosed the cyst (Fig. 2); yet, in these instances no degenerative changes in the myocardial cells were found. The capsule formed by the host's reaction to the parasite (Figs. 1 \& 7) measured 13.57 to $90.27 \mu \mathrm{m}$ (mean $=37.43 \pm 3.56 \mathrm{SE} \mu \mathrm{m})$ in thickness; its structure appeared to comprise a series of concentric whorls of fibroconnective elements (Figs. 1 $\& 10)$. Within the fibres, the presence of eosinophilic granular cells, granulocytes, melanocytes and, occasionally, partially degenerated or vacuolated epithel- 

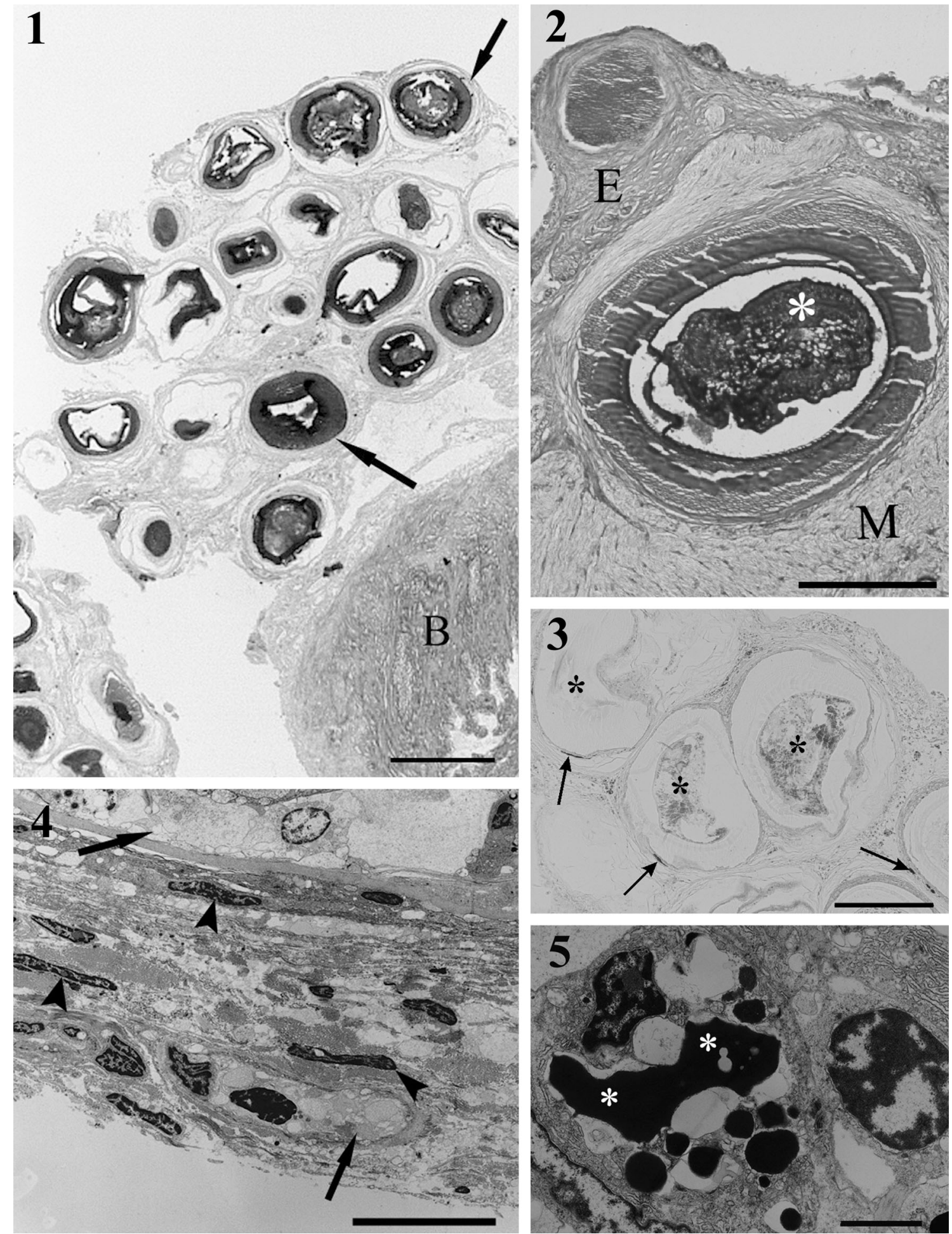

Figs. 1 to 5. Coregonus lavaretus hearts infected with Ichthyocotylurus erraticus. Fig. 1. High number of I. erraticus metacercarial cysts near bulbus arteriosus (B) of C. lavaretus; each cyst is surrounded by proliferation of granulomatous tissue derived from heart epicardium (arrows) (scale bar $=300 \mu \mathrm{m}$ ). Fig. 2. Occasionally, metacercaria (asterisk) was observed to penetrate myocardium $(\mathrm{M})$; E: epicardium (scale bar $=200 \mu \mathrm{m}$ ). Fig. 3. Macrophage aggregates (arrowed) around metacercariae $($ asterisks) $($ scale bar $=200 \mu \mathrm{m})$. Fig. 4. Micrograph of outer part of capsule enclosing I. erraticus cyst; epithelioid (arrowheads) and vacuolised (arrowed) cells are present (scale bar $=3 \mu \mathrm{m}$ ) Fig. 5. Electron micrograph of fused granules (asterisks) within eosinophilic granular cell (scale bar $=1 \mu \mathrm{m})$ 

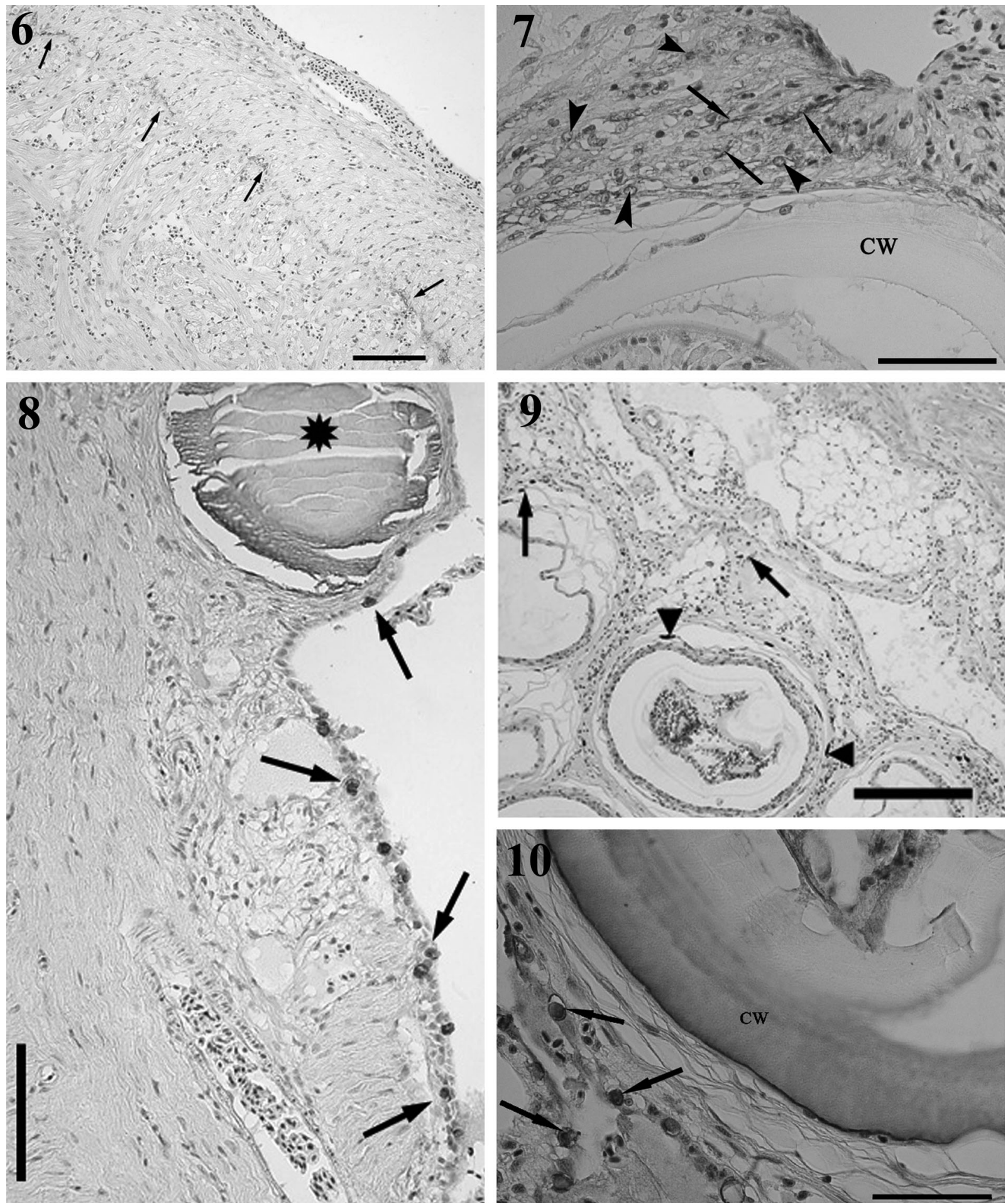

Figs. 6 to 10. Coregonus lavaretus hearts infected with Ichthyocotylurus erraticus. Fig. 6. Nerve fibres (arrowed) within infected heart tissue that are immunoreactive to anti-substance P serum (scale bar $=100 \overline{\mu \mathrm{m}}$ ). Fig. 7 . Micrograph showing presence of nerve fibres (arrowed) positive to anti-bombesin serum; a high number of different cell types adjacent to body wall of the cyst $(\mathrm{CW})$ can also be seen (arrowheads) (scale bar $=50 \mu \mathrm{m}$ ). Fig. 8. Large circular cells (arrowed) within epicardium that were immunoreactive to met-enkephalin serum; asterisk marks metacercaria encysted on surface of heart (scale bar $=100 \mu \mathrm{m})$. Fig. 9 . Immunoreactive cells (arrowed) containing serotonin-like substance within inflamed connective tissue; several melanomacrophages (arrowheads) around metacercariae are also evident (scale bar $=200 \mu \mathrm{m}$ ). Fig. 10. High magnification of large, circular cells close to body wall of cyst that yield positive reaction to vasoactive intestinal peptide (arrowed) (scale bar $=50 \mu \mathrm{m})$ 
ioid cells in close proximity to the body wall of the cyst were observed (Figs. $4,7 \& 10$ ). In some hearts, there was fusion of the granules of the EGCs that were in close proximity to the metacercariae (Fig. 5). In 7 fish, single pigment-bearing macrophages ('melanomacrophages') as well as macrophage aggregates were observed within the parasite capsule (Fig. 3). Histological staining of the parasite cyst wall produced an intense positive reaction with PAS and a faint positive reaction with Azan-Mallory stain.

In the epicardium of infected hearts, immunohistochemical testing revealed several nerve fibres that were positive to the anti-substance P serum (Fig. 6). In addition to these, a network of thin nerve fibres that were immunoreactive to the anti-bombesin serum were observed in the fibroconnective capsule enclosing the parasites (Fig. 7) as were several cells containing a serotonin-like substance in the fibroconnective tissue surrounding the parasite larvae (Fig. 9). Within the epicardium, numerous large and round-shaped elements that were immunoreactive to the metenkephalin and the vasoactive intestinal peptide antisera increased in density in the vicinity of a metacercarial cyst (Figs. 8 \& 10).

In the powan sampled in this study, females harboured a greater number of Ichthyocotylurus erraticus metacercariae on their hearts than males. A similar observation was made by Dolezel \& Crompton (2000) who also conducted an examination of powan in Loch Lomond. These observed differential loadings cannot be attributed to a single cause, but result from (among other factors) differences in age, host physiology and diet (Kennedy 1975). In the present study, the 2 largest fish ( $36 \mathrm{~cm}$ and $37 \mathrm{~cm}$ long), both of which were female, most likely represented the oldest fish in the sample. These 2 fish also had the heaviest infections, with 170 and 200 metacercariae respectively. In the sheepshead minnow Cyprinodon variegatus variegatus Lacepède infected with metacercariae of Ascocotyle pachycystis (Schroeder \& Leigh, 1965), the largest fish were shown to be the oldest, and had the heaviest parasitic infections (Coleman \& Travis 1998). According to Polyanski (1961), larger hosts provide more habitats suitable for parasites and, as Kennedy (1975) suggested, the older a host, the longer the period in which it can come into contact with a parasite. The small number of fish sampled in the current study, however, does not permit us to draw any confident conclusions regarding the relationship between the length and/or age of the host and the degree of $I$. erraticus infection.

The metacercariae of the related Cotylurus spp. are not restricted to the pericardial cavity (Odening et al. 1970, Olson 1970, Grabda 1971, Swennen et al. 1979, Orecka-Grabda 1991), but have been found distributed throughout a number of body organs including the swimbladder (Swennen et al. 1979), the eyes and body cavity (Blair 1976, Smith \& Noga 1993) and the kidney and liver (Orecka-Grabda 1991). However, according to Noga (2000) the presence of metacercariae are almost always innocuous, although if they displace enough fish tissue, they can compromise organ functions. For example, heterophyid metacercariae may induce severe gill damage, decrease respiratory tolerance and can result in the mortality of warm-water fish species (Paperna 1991). Similarly, the metacercariae of Apharyngostrigea cornu (Zeder, 1800) that occur in the peritoneum and the mesenteries of some cyprinid fish species are known to cause haemorrhaging and fish death (e.g. the mortality of European populations of grass carp) (Hoole et al. 2001). In salmonids, high intensities of I. erraticus metacercariae on the hearts of the whitefish Coregonus albula (L.), have been known to cause mortalities (Orecka-Grabda 1991, D. Griffiths pers. comm.).

In the literature, 2 accounts also detail the impact that metacercariae have on heart performance. Tort et al. (1987) documented changes in the in vitro performance of rainbow trout hearts parasitised with the metacercarial cysts of Apatemon gracilis: the cardiac output of the infected hearts was 20 to $40 \%$ less than that of uninfected hearts. Such reductions will, in turn, lead to reduced oxygen delivery to the fish's tissues, with impairment in swimming activity and growth (Tort et al. 1987). This was confirmed by the investigation of Coleman (1993) who determined a reduction in the swimming performance of sheepshead minnow whose hearts were infected with Ascocotyle pachycystis metacercariae. Coleman (1993) observed hypertrophication of the ventricle, a compensatory response to the mechanical blockage caused by the presence of parasites within the bulbus. Blockages of this type place increasing demands on the respiratory system to deliver oxygen to the tissues, which can increase the incidence of mortality through irregular cardiac performance, reduced metabolic scope (Priede 1977) or impaired swimming performance (Coleman 1993). The present study revealed an inflammatory response and encapsulation of the Ichthyocotylurus erraticus metacercariae in the hearts of infected powan. Based on experimental records for the analogous situations presented by Tort et al. (1987) and by Coleman (1993), it is reasonable to presume that a medium-to-high number of metacercariae are not innocuous to their fish host and that such numbers are likely to impair the normal functioning of heart tissue. Whether this tissue damage is reflected in the physiological dysfunction of the powan's heart can only be ascertained by specific experimental demonstration. I. erraticus metacercariae situated in and on the hearts of Coregonus lavaretus were surrounded by a reactive fibroconnective tissue 
capsule produced by the host's reaction to the presence of the parasites. Similar host tissue-reactions were reported by Orecka-Grabda (1991) for the hearts and kidneys of $C$. albula infected with $I$. erraticus, by Dolezel \& Crompton (2000) on the infected hearts of powan from Loch Lomond, and by Rojas et al. (1999) in the muscles of Caprodon longimanus (Günther) parasitised with the metacercariae of Manteria sp. (Caballero, 1950). During the present study, using an electron microscope, we documented the cell types scattered among the fibres within the capsule (e.g. aggregations of MAs, EGCs and epithelioid cells) at the interface between host and parasite. The MAs were observed in histological sections of 14 powan hearts, and their proliferation has been frequently associated with both physiological and pathological factors including starvation, aging, intoxication and the presence of infectious disease (Vogelbein et al. 1987, Couillard \& Hodson 1996, Couillard et al. 1999). The presence of MAs have been reported for Rivulus marmoratus (Poey) experimentally infected with the protozoan Calyptospora funduli Overstreet, Hawkins \& Fournie, 1984 (Vogelbein et al. 1987) and also for Gasterosteus aculeatus infected with the microsporean Glugea anomala (Dezfuli et al. 2004). In the study of Vogelbein et al. (1987), who found MAs in association with parasite infections, it was suggested that their presence represents an inflammatory rather than a granulomatous reaction. The findings of the current study and those of Dezfuli et al. (2004) lend support to Vogelbein et al.'s (1987) hypothesis.

The presence and nature of eosinophilic granular cells within the capsule, however, is still a matter of debate. These cells are part of the host's inflammatory response and have been reported from the sites of parasite infection (Ferguson 1989, Reite 1998). They have also been encountered in the liver, pancreas and peritoneal serosa of minnows Phoxinus phoxinus (L.), infected with the larvae of the nematode Raphidascaris acus Bloch, 1779 (Dezfuli et al. 2000). With reference to the presence of epithelioid cells in the capsule, Noga et al. (1989) suggested that piscine epithelioid cells may represent an alternative type of epithelial inflammatory cell. These cells were also noted in the infected tissues of $P$. phoxinus (Dezfuli et al. 2000). In addition to the cell types already described, several cells containing a serotonin-like substance were also observed in the fibroconnective tissue surrounding Ichthyocotylurus erraticus cysts. This antiserum has been used to reveal the presence of fish mast-cells (Khan \& Deschaux 1997) and have been reported in Salmo trutta infected with the spathebothriid cestode Cyathocephalus truncatus (Dezfuli et al. 2000).

In vertebrates, the intrinsic cardiac nervous system exhibits a range of different morphological and immunohistochemical properties (Holmgren et al. 1994, Horackova et al. 1999, Kuncova et al. 2003). Blood pressure and heart rate are regulated by circulating neuropeptides which involve the brain-cardiac axis (Xiang 1994, Matsumara et al. 2003, Pedrazzini et al. 2003) and by endogenous molecules synthesised by heart neurons (Lillywhite et al. 1999). While many studies have dealt with the distribution and physiological effect of several neuropeptides on vertebrate hearts (Masini et al. 1997, Wong et al. 1998, Henning \& Sawmiller 2001), there has been very little work on how parasites can induce alterations in the cardiac intrinsic nervous system (Camargos et al. 2002, Rodrigues et al. 2002). Of the records that do exist, none refer to parasitic infections in fishes.

In the current study, 11 neuropeptides were tested on histological sections of infected powan hearts. Of those that were tested, reactions to substance P (SP), bombesin, atrial natriuretic peptide (ANP), metenkephalin and vasoactive intestinal peptide (VIP) antisera were observed in the nerve fibres and nerve cell bodies, whereas calcitonin gene-related peptide (CGRP), galanin, nitric oxide synthase (NOS) and neuropeptide Y (NPY) antisera gave negative results.

A reaction to the anti-SP serum was observed in the nerve fibres of the epicardium. This neuropeptide has also been reported in the hearts of mammals (Abrahamian et al. 1991, Onuhoa et al. 1999), elasmobranchs (Waugh et al. 1993), and teleosts (Davies et al. 1994, Holmgren et al. 1994, Waugh et al. 1995). Although the function of SP within the capsule enclosing the metacercariae is currently unknown, an injection of SP into the bulbus arteriosus of non-anesthetised bowfin, Amia calva (L.) resulted in a significant and dose-dependent rise in arterial blood pressure (Waugh et al. 1995). From our observations on the localisation of nerve fibres responding to the anti-SP serum in the current study, it could be postulated that the presence of SP within the hearts of infected powan serves to stimulate blood flow through vascularisation of the developing cyst.

In the Coregonus lavaretus-infected hearts, a bombesin-like substance was observed throughout a network of subtle nerve fibres within the fibroconnective capsule enclosing Ichthyocotylurus erraticus metacercariae. In other fish-parasite studies, this neuropeptide was observed in the connective tissue capsule produced by the gut of Salmo trutta in response to the acanthocephalan Pomphorhyncus laevis (Dezfuli et al. 2002a). A bombesin-like substance was also encountered within the thin nerve fibres in the inflammatory connective tissue of Gasterosteus aculeatus infected with the protozoan Glugea anomala (Dezfuli et al. 2004). The findings from these and those of the current study support the hypothesis of Dezfuli et al. (2004), who suggested that the presence of bombesin 
at the site of tissue inflammation in fishes acts as a putative neurotransmitter in the neo-formed network of nervous fibres.

Of the studies that do exist on the neuropeptides of fish hearts, the majority have focused on ANP (Donald et al. 1992, Loretz \& Pollina 2000). In the current study, an ANP-like substance was found in the nerve fibres and nerve cell bodies of the powan hearts. The natriuretic peptide system plays a pivotal role in cardiovascular and body fluid homeostasis (Takey 1999), and both hypernatremia (high amounts of sodium in the blood) and hypervolemia (an increase in the volume of circulating blood) in teleosts have been shown to be effective stimuli for the cardiac secretion of natriuretic peptides such as ANP (Loretz \& Pollina 2000).

Immunohistochemical staining also demonstrated the presence and accumulation of nerve fibres and neuronal bodies that were positive to anti-metenkephalin and -VIP sera in close proximity to the Ichthyocotylurus erraticus metacercariae. Dezfuli et al. (2000, 2002b) made similar observations for antimetenkephalin and-VIP in the enteric neuroendocrine system of Salmo trutta infected with intestinal helminths. Enkephalin-immunoreactive nerve fibres and cell bodies have also been observed in the hearts of guinea-pigs (Steele et al. 1994, 1996) —in mammals, opioid peptides appear to regulate the autonomic control of the heart (Barron et al. 1995). VIP has also been observed in the post-ganglionic parasympathetic nerves of mammalian hearts (Onuhoa et al. 1999, Henning \& Sawmiller 2001, Kuncova et al. 2003) and in several fish species (Davies et al. 1994, Holmgren et al. 1994), in which it is believed that VIP plays an important role in the regulation of coronary blood flow, cardiac contraction and relaxation, as well as heart rate (Henning \& Sawmiller 2001). The anti-protein geneproduct 9.5 (PGP9.5) serum is a general neuronal marker and is used in rats to identify all intracardiac neurons (Richardson et al. 2003). Immunohistochemical staining of infected powan heart sections with the PGP9.5 antisera gave negative results; however, the nature and function of the large cells of the epicardium that were positive to VIP and met-enkephalin are intriguing, and further investigations on their role in the host-parasite interaction are necessary. It is anticipated that this ongoing work will elucidate the effects of $I$. erraticus metacercarial infections on the functional physiology of the powan heart.

Acknowledgements. Thanks are due to Stuart Wilson from the Rowardennan Field Station at Loch Lomond for his assistance in collecting powan. This investigation was supported through an award to BSD from the European Union Access to Research Infrastructures (ARI) Action of the Improving Human Potential (IHP) Programme (contract HPRI-CT-200100180).

\section{LITERATURE CITED}

Abrahamian S, Fodor M, Gorcs T, Galoyan A, Palkovits M (1991) Neuropeptides in atrial subepicardial ganglia of rats. Acta Morphol Hung 39:267-278

Barron B, Oakford LX, Gaugl JF, Caffrey JL (1995) Methionine-enkephalin-arg-phe immunoreactivity in heart tissue. Peptides (NY) 16:1221-1227

Blair D (1976) Observations on the life-cycle of the strigeoid trematode, Apatemon (Apatemon) gracilis (Rudolphi, 1819) Szidat, 1928. J Helminthol 50:125-131

Blair D (1977) A key to cercariae of British strigeoids (Digenea) for which the life-cycle are known, and notes on the characters used. J Helminthol 51:155-166

Brown EAR, Scott DBC (1994) Life histories of the powan, Coregonus lavaretus (L.) (Salmonidae, Coregonidae) of Loch Lomond and Loch Eck. Hydrobiologia 290:121-133

Camargos ER, Machado CR, Teixeira AL Jr, Rocha LL, Ferreira AJ, Almeida AP, Barton M, Teixeira MM (2002) Role of endothelin during experimental Trypanosoma cruzi infections in rats. Clin Sci 103:64S-67S

Castro GA (1992) Intestinal physiology in the parasitised host: integration, disintegration, and reconstruction of systems. Ann NY Acad Sci 664:369-379

Coleman FC (1993) Morphological and physiological consequences of parasites encysted in the bulbus arteriosus of an estuarine fish, the sheepshead minnow, Cyprinodon variegates. J Parasitol 79:247-254

Coleman FC, Travis J (1998) Phenology of recruitment and infection patterns of Ascocotyle pachycystis, a digenean parasite in the sheepsheed minnow, Cyprinodon variegates. Environ Biol Fish 51:87-96

Couillard CM, Hodson PV (1996) Pigmented macrophage aggregates: a toxic response in fish exposed to bleachedkraft mill effluent? Environ Toxicol Chem15:1844-1854

Couillard CM, Williams PJ, Courtenay SC, Rawn GP (1999) Histopathological evaluation of Atlantic tomcod (Microgadus tomcod) collected at estuarine sites receiving pulp and paper mill effluent. Aquat Toxicol (Amst) 44:263-278

Davies PJ, Donald JA, Campbell G (1994) The distribution and colocalization of neuropeptides in fish cardiac neurons. J Aut Nerv Syst 46:261-272

Dezfuli BS, Arrighi S, Domeneghini C, Bosi G (2000) Immunohistochemical detection of neuromodulators in the intestine of Salmo trutta L. naturally infected with Cyathocephalus truncatus Pallas (Cestoda). J Fish Dis 23:265-273

Dezfuli BS, Giari L, Simoni E, Bosi G, Manera M (2002a) Histopathology, immunohistochemistry and ultrastructure of the intestine of Leuciscus cephalus (L.) naturally infected with Pomphorhynchus laevis (Acanthocephala). $\mathrm{J}$ Fish Dis 25:7-14

Dezfuli BS, Pironi F, Giari L, Domeneghini C, Bosi G (2002b) The effect of Pomphorhynchus laevis (Acanthocephala) on occurrence and distribution of putative neuromodulators in the intestine of naturally infected Salmo trutta (L.). Dis Aquat Org 51:27-35

Dezfuli BS, Giari L, Arrighi S, Domeneghini C, Bosi G (2003a) Influence of enteric helminths on the distribution of intestinal endocrine cells belonging to the diffuse endocrine system in brown trout, Salmo trutta L. J Fish Dis 26:155-166

Dezfuli BS, Giari L, Konecny R, Jaeger P, Manera M (2003b) Immunohistochemistry, ultrastructure and pathology of gills of Abramis brama from Lake Mondsee, Austria, infected with Ergasilus sieboldi (Copepoda). Dis Aquat Org 53:257-262

Dezfuli BS, Giari L, Simoni E, Shinn AP, Bosi G (2004) 
Immunohistochemistry, histopathology and ultrastructure of Gasterosteus aculeatus tissues infected with Glugea anomala. Dis Aquat Org 58:193-202

Dolezel MC, Crompton DWT (2000) Platyhelminth infection in powan Coregonus lavaretus (L.), from Loch Eck and Loch Lomond, Scotland. Helminthologia 37:147-152

Donald JA, Vomachka AJ, Evans DH (1992) Immunohistochemical localization of natriuretic peptides in the brains and hearts of the spiny dogfish Squalus acanthias and the Atlantic hagfish Myxine glutinosa. Cell Tissue Res 270: 535-545

Fairweather I (1997) Peptides: an emerging force in host response to parasitism. In: Beckage NE (ed) Parasites and pathogens: effects on host hormones and behaviour. Chapman \& Hall, New York, p 113-139

Ferguson HW (1989) Systemic pathology of fishes. Iowa State University Press, Ames, IA

Grabda J (1971) Catalogus faunae parasiticae Poloniae. In: Grabda E, Jaczewski T, Kazubski SL (eds) Parasiti Cyclostomatorum et Piscium. Panstwowe Wydawnictwo Naukowe, Warszawa-Wrocłam, p 150-170

Henning RJ, Sawmiller DR (2001) Vasoactive intestinal peptide: cardiovascular effects. Cardiovasc Res 49:27-37

Holmgren S, Fritsche R, Karila P, Gibbins I, Axelsson M, Franklin C, Grigg G, Nilsson S (1994) Neuropeptides in the Australian lungfish Neoceratodes forsteri: effects in vivo and presence in autonomic nerves. Am J Physiol Reg I 266:R1568-R1577

Hoole D, Bucke D, Purgess P, Welby I (2001) Infectious diseases - parasite. In: Hoole D, Bucke D, Purgess P, Welby I (eds) Diseases of carp and other cyprinid fishes, Chap 5. Blackwell Science, Oxford, p 63-124

Horackova M, Armour JA, Byczko Z (1999) Distribution of intrinsic cardiac neurons in whole-mount guinea pig atria identified by multiple neurochemical coding: a confocal microscope study. Cell Tissue Res 297:409-421

Khan NA, Deschaux P (1997) Perspective role of serotonin fish immunomodulation. J Exp Biol 200:1833-1838

Kennedy CR (1975) Dispersion of parasites within a hostparasite system. In: Kennedy CR (ed) Ecological animal parasitology. Blackwell Scientific Publications, Oxford, p 61-75

Kuncova J, Slavikova J, Reischig J (2003) Distribution of vasoactive intestinal polypeptide in the rat heart: effect of guanethidine and capsaicin. Ann Anat 185:153-161

Lillywhite HB, Zippel KC, Farrell AP (1999) Resting and maximal heart rates in ectothermic vertebrates. Comp Biochem Physiol A 124:369-382

Loretz CA, Pollina C (2000) Natriuretic peptides in fish physiology. Comp Biochem Physiol A 125:169-187

Masini MA, Sturla M, Uva BM (1997) Vasoactive peptides in the heart of Champsocephalus gunnari. Comp Biochem Physiol A 118:1083-1086

Matsumara K, Tsuchihashi T, Fujii K, Iida M (2003) Neural regulation of blood pressure by leptin and the related peptides. Regul Pep 114:79-86

Noga EJ (2000) Fish disease: diagnosis and treatment. Iowa State University Press, Ames, IA

Noga EJ, Dykstra MJ, Wright JF (1989) Chronic inflammatory cells with epithelial cell characteristics in teleost fishes. Vet Pathol 26:429-437

Odening K, Mattheis T, Bockhardt I (1970) Der Lebenszyklus von Cotylurus c. cucullus (Thoss) (Trematoda, Strigeida) im Raum Berlin. Zool Jahrb Alt Syst Ökol Geogr Tiere 97: 128-198

O'Dorisio MS, Panerai A (1990) Neuropeptides and immunopeptides:messengers in a neuroimmune axis. Ann
NY Acad Sci 594:1-503

Olson RE (1970) The life cycle of Cotylurus erraticus (Rudolphi, 1809) Szidat, 1928 (Trematoda: Strigeidae). J Parasitol 56:55-63

Onuhoa GN, Alpar EK, Chukwulobelu R, Nicholls DP (1999) Distributions of VIP, substance P, neurokinin A and neurotensin in rat heart: an immunocytochemical study. Neuropeptides 33:19-25

Orecka-Grabda T (1991) Remato- and histopathological changes in the whitefish (Coregonus albula (L.) invaded by metacercariae of Cotylurus erraticus (Syn. Ichthyocotylurus) (Rudolphi, 1809). Fish Pathol 221 : 3-19

Paperna I (1991) Diseases caused by parasites in the aquaculture of warm water fish. Annu Rev Fish Dis 1:155-194

Pedrazzini T, Pralong F, Grouzmann E (2003) Neuropeptide Y: the universal soldier. Cell Mol Life Sci 60:350-377

Polyanski Y (1961) Ecology of parasites of marine fishes. In: Dogiel VA, Petrushevsky GK, Polyanski Yu I (eds) Parasitology of fish. Oliver \& Boyd, Edinburgh, p 48-83

Pomeroy PP (1991) A comparative assessment of temporal variation in the diet of powan, Coregonus lavaretus (L.), from Loch Lomond and Loch Eck, Scotland, UK. J Fish Biol 38:457-478

Priede IG (1977) Natural selection for energetic efficiency and the relationship between activity level and mortality. Nature 267:610-611

Reite OB (1998) Mast cells/eosinophilic granule cells of teleostean fish: a review focusing on staining properties and functional responses. Fish Shellfish Immunol 8: $489-513$

Richardson RJ, Grkovic I, Anderson CR (2003) Immunohistochemical analysis of intracardiac ganglia of the rat heart. Cell Tissue Res 314:337-350

Rodrigues E, Liberti EA, Maifrino LB, de Souza RR (2002) Cardiac denervation in mice infected with Trypanosoma cruzi. Ann Trop Med Parasitol 96:125-130

Rojas JR, Torres P, Pequeño G (1999) Acanthocolpid metacercariae in the sea bass from Alejandro Selkirk Island, Chile. J Wildl Dis 35:90-93

Steele PA, Gibbins IL, Morris JL, Mayer B (1994) Multiple populations of neuropeptide containing neurons in the guinea-pig heart. Neuroscience 62:241-250

Steele PA, Aromataris EC, Riederer BM (1996) Endogenous opioid peptides in parasympathetic, sympathetic and sensory nerves in the guinea-pig heart. Cell Tissue Res 284: 331-339

Smith SA, Noga E (1993) General Parasitology. In: Stoskopf ML (ed) Fish medicine, Chap 10. WB Saunders, Philadelphia, p 132-148

Swennen C, Heessen HJ, Hocker WM (1979) Occurrence and biology of the trematodes Cotylurus (Ichthyocotylurus) erraticus, C. (I.) variegates and C. (I.) platycephalus (Digenea: Strigeidae) in the Netherlands. Neth J Sea Res 13:161-191

Takey Y (1999) Structural and functional evolution of the natriuretic peptide system in vertebrates. Int Rev Cytol 194:1-66

Tort L, Watson JJ, Priede GI (1987) Changes in in vitro heart performance in rainbow trout, Salmo gairdneri Richardson, infected with Apatemon gracilis (Digenea). J Fish Biol 30:41-347

Vogelbein WK, Fournic JW, Overstreet RM (1987) Sequential development and morphology of experimentally induced melano-macrophage centres in Rivulus marmoratus. J Fish Biol 31:145-153

Waugh D, Wang Y, Hazon N, Balment RJ, Conlon JM (1993) Primary structures and biological activities of substance- 
P-related peptides from the brain of the dogfish, Scyliorhinus canicula. Eur J Biochem 214:469-474

Waugh D, Groff KE, Platzack B, Youson JH, Olson KR, Conlon JM (1995) Isolation, localization and cardiovascular activity of tachykinins from the stomach of the bowfin Amia calva. Am J Physiol-Reg I 269:R565-R571

Wolke RE (1992) Piscine macrophage aggregates: a review. Annu Rev Fish Dis 2:91-108

Wong AOL, Leung MY, Shea WLC, Tse LY, Chang JP, Chow

Editorial responsibility: Wolfgang Körting,

Hannover, Germany
BKC (1998) Histophysiotropic action of pituitary adenylate cyclase-activating polypeptide (PACAP) in the goldfish: immunohistochemical demonstration of PACAP in the pituitary, PACAP stimulation of growth hormone release from pituitary cells, and molecular cloning of pituitary type I PACAP receptor. Endocrinology 139:3465-3479

Xiang H (1994) Comparative aspects of the role of neuropeptide $\mathrm{Y}$ in the regulation of the vertebrate heart. Cardioscience 5:209-213

Submitted: January 3, 2005; Accepted: March 10, 2005

Proofs received from author(s): September 5, 2005 